\title{
The Hydrogeological Model of Latvia LAMO4 as a Tool for Investigating the Processes of Nature. Sources of Groundwater Inflow for the Iecava River
}

\author{
Kaspars Krauklis ${ }^{1}$, Aivars Spalvins ${ }^{2}$, Janis Slangens ${ }^{3}$ \\ ${ }^{1-3}$ Riga Technical University
}

\begin{abstract}
In 2010-2012, the hydrogeological model (HM) of Latvia (LAMO) was established by the scientists of Riga Technical University (RTU). In 2013-2014, LAMO was upgraded. In 2015, the recent version LAMO4 was developed. In LAMO4, the plane approximation step was decreased from $\mathbf{5 0 0}$ meters to 250 meters. The base flows of rivers for HM were adjusted by accounting for data that were provided by the measurements of river streams. LAMO is run by the commercial program Groundwater Vistas $(\mathrm{GV})$, version 6 . It contains the MODFOW and MODPATH programs for supporting HM and for tracking groundwater particles, respectively. By using MODPATH, the case of the Iecava river was investigated in order to find the sources that support groundwater inflow into the river (its base flow). Unforeseen results were obtained. Due to the appliance of the large regional HM, it was discovered that some part of the river base flow comes from the areas that are located very far from the river drainage basin. It also was not expected that even within the basin the particle traces were very complex. The results described in the paper serve as demonstration for the usefulness of applying a large complex HM for investigating the processes of nature.
\end{abstract}

Keywords - Base flow of river, hydrogeological model, particle tracking, Latvia.

\section{INTRODUCTION}

In 2010-2012, the HM LAMO was established by the scientists of RTU. LAMO simulates the steady-state mean hydrogeological situation of Latvia. In Fig. 1, the location of LAMO is shown. LAMO includes 27 geological layers (see Fig. 2). The GV program is used for running LAMO [1]. In 2013-2015, LAMO was considerably updated [2], [3]. In 2015, the latest LAMO4 version was developed. By using LAMO4, the first attempt has been done to use this large regional $\mathrm{HM}$ as a tool for investigating the processes of nature by searching for sources that support the base flow of a river. The case of the Iecava river was explored. The river is located in the flat land area of the country (Fig. 3). Its elevations are $68.5 \mathrm{~m}$ asl and $0.2 \mathrm{~m}$ asl for the source and mouth of the river, accordingly. The drainage basin area is $1174.2 \mathrm{~km}^{2}$ (Fig. 3). It includes the area of the small tributaries Smakupe and Girupe.
In Fig. 4, the vertical cross section (above $100 \mathrm{~m}$ asl) along the Iecava river is shown. It follows from the exposed stratigraphy that the river drainage basin does not include the layers 5-12 of Fig. 2, because they do not exist there. The Iecava river lies into the Quaternary aquifer Q2, and the primary aquifer D3dg\# is located just beneath the river.

In Table I, the groundwater balance for the drainage basin of the Iecava river is presented. It was obtained by using the GV mass balance tool for the all layers of the basin (1st row in Table I) and for the Q2 aquifer (2nd row). The balance for the primary aquifers (3rd row) is the difference between the 1st and 2nd row. Only for the Q2 aquifer, the full set of flows is available for top and bottom surfaces of the layer. The following conclusions can be drawn from the data of Table I:

a part of the infiltration flow 172 thous. $\mathrm{m}^{3} /$ day turns into the surface water runoff ( -31 thous. $\mathrm{m}^{3} / \mathrm{day}$ );

through the drainage basin border, a notable inflow $q_{\text {norde }}=9$ thous. $\mathrm{m}^{3} /$ day exists; it contains mainly the flow of the primary layers ( 10 thous. $\mathrm{m}^{3} /$ day);

the Iecava river is connected not only with the Quarernary but also with the primary D3dg\# layer $\left(q_{\text {river }}=-147=-(135+12)\right.$, respectively;

the flows $q_{\text {botin }}$ and $q_{\text {botout }}$ for the Q2 aquifer are equal ( \pm 93 thous. $\mathrm{m}^{3} /$ day)

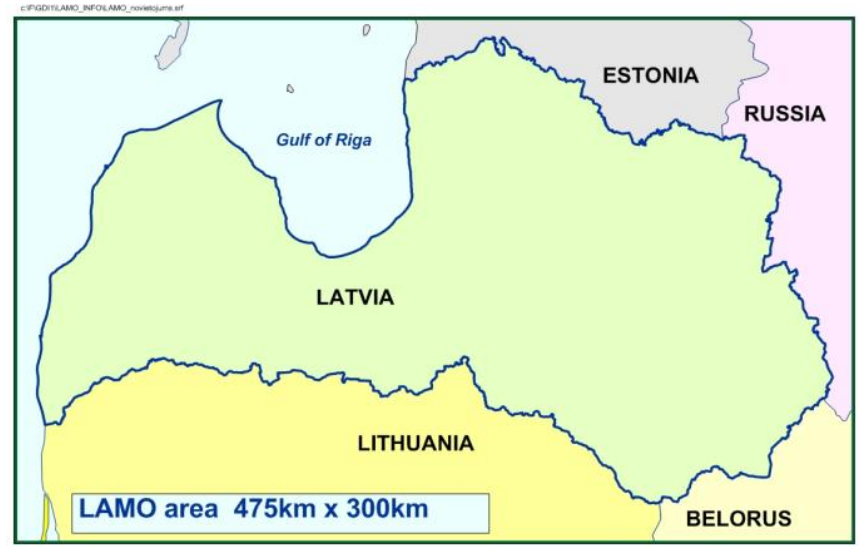

Fig. 1. Location of LAMO

TABLE I

GROUNDWATER FLOW, THOUS. M³/DAY, BALANCE FOR THE DRAINAGE BASIN OF THE IECAVA RIVER

\begin{tabular}{|l|l|l|l|l|l|l|l|l|l|}
\hline Name of object & $q_{\text {topin }}$ & $q_{\text {topout }}$ & $q_{\text {botin }}$ & $q_{\text {botout }}$ & $q_{\text {inflow }}$ & $q_{\text {river }}$ & $q_{\text {lake }}$ & $q_{\text {hor }}$ & $q_{\text {well }}$ \\
\hline Basin & 172 & -31 & & & 141 & -2147 & 0 & 9 & -3 \\
\hline Q2 & 167 & -31 & 93 & -93 & 136 & -135 & 0 & -1 & 0 \\
\hline Primary aquifer & 5 & & & & 5 & -12 & 0 & 10 & -3 \\
\hline
\end{tabular}




\begin{tabular}{|c|c|c|c|}
\hline $\begin{array}{l}\text { No of } \\
\text { HM } \\
\text { plane }\end{array}$ & Name of layer & $\begin{array}{l}\text { Geolo- } \\
\text { gical } \\
\text { code }\end{array}$ & $\begin{array}{l}\text { HM } \\
\text { plane } \\
\text { code }\end{array}$ \\
\hline 1. & Relief & relh & relh \\
\hline 2. & Aeration zone & aer & aer \\
\hline 3. & $\begin{array}{l}\text { Unconfined } \\
\text { Quaternary }\end{array}$ & Q4-3 & Q2 \\
\hline 4. & Upper moraine & gQ3 & $\mathrm{gQ} 22$ \\
\hline 5. & $\begin{array}{l}\text { Confined } \\
\text { Quaternary or } \\
\text { Jura }\end{array}$ & $\begin{array}{l}\text { Q1-3 } \\
J\end{array}$ & Q1\# \\
\hline 6. & $\begin{array}{l}\text { Lower moraine } \\
\text { or Triass }\end{array}$ & $\begin{array}{l}\text { gQ1-3 } \\
\mathrm{T}\end{array}$ & gQ1\#z \\
\hline 7. & $\begin{array}{l}\text { Perma } \\
\text { Karbons } \\
\text { Skerveles } \\
\text { Ketleru }\end{array}$ & $\begin{array}{l}\text { P2 } \\
\text { C1 } \\
\text { D3šk } \\
\text { D3ktl }\end{array}$ & D3ktl\# \\
\hline 8. & Ketleru & D3ktl & D3ktlz \\
\hline 9. & $\begin{array}{l}\text { Zagares } \\
\text { Svetes } \\
\text { Tervetes } \\
\text { Muru }\end{array}$ & $\begin{array}{l}\text { D3žg } \\
\text { D3sv } \\
\text { D3tr } \\
\text { D3mr }\end{array}$ & D3zg\# \\
\hline 10. & Akmenes & D3ak & D3akz \\
\hline 11. & $\begin{array}{l}\text { Akmenes } \\
\text { Kursas } \\
\text { Jonisku }\end{array}$ & $\begin{array}{l}\text { D3ak } \\
\text { D3krs } \\
\text { D3jn }\end{array}$ & D3krs\# \\
\hline 12. & $\begin{array}{l}\text { Elejas } \\
\text { Amulas }\end{array}$ & $\begin{array}{l}\text { D3el } \\
\text { D3aml }\end{array}$ & D3el\#z \\
\hline 13. & $\begin{array}{l}\text { Stipinu } \\
\text { Katlesu } \\
\text { Ogres } \\
\text { Daugavas }\end{array}$ & $\begin{array}{l}\text { D3stp } \\
\text { D3ktl } \\
\text { D3og } \\
\text { D3dg }\end{array}$ & D3dg\# \\
\hline 14. & $\begin{array}{l}\text { Daugavas } \\
\text { Salaspils }\end{array}$ & $\begin{array}{l}\text { D3dg } \\
\text { D3slp }\end{array}$ & D3slp\#z \\
\hline 15. & Plavinu & D3pl & D3pl \\
\hline 16. & $\begin{array}{l}\text { Plavinu } \\
\text { Amatas }\end{array}$ & $\begin{array}{l}\text { D3pl } \\
\text { D3am }\end{array}$ & D3am\#z \\
\hline 17. & Amatas & D3am & D3am \\
\hline 18. & Upper Gauja & D3gj2 & D3gj2z \\
\hline 19. & Upper Gauja & D3gj2 & D3gj2 \\
\hline 20. & Lower Gauja & D3gj1 & D3gj1z \\
\hline 21. & Lower Gauja & D3gj1 & D3gj1 \\
\hline 22. & Burtnieku & D2brt & D2brtz \\
\hline 23. & Burtnieku & D2brt & D2brt \\
\hline 24. & Arikula & D2ar & D2arz \\
\hline 25. & Arikula & D2ar & D2ar \\
\hline 26. & $\begin{array}{l}\text { Narvas } \\
\text { Narvas }\end{array}$ & $\begin{array}{l}\mathrm{D} 2 \mathrm{nr} 2 \\
\mathrm{D} 2 \mathrm{nr} 1\end{array}$ & D2nr\#z \\
\hline 27. & Pernavas & D2prn & $\mathrm{D} 2 \mathrm{pr}$ \\
\hline
\end{tabular}

\#-united aquifer; \#z-united aquitard

Fig. 2. Vertical schematization of LAMO

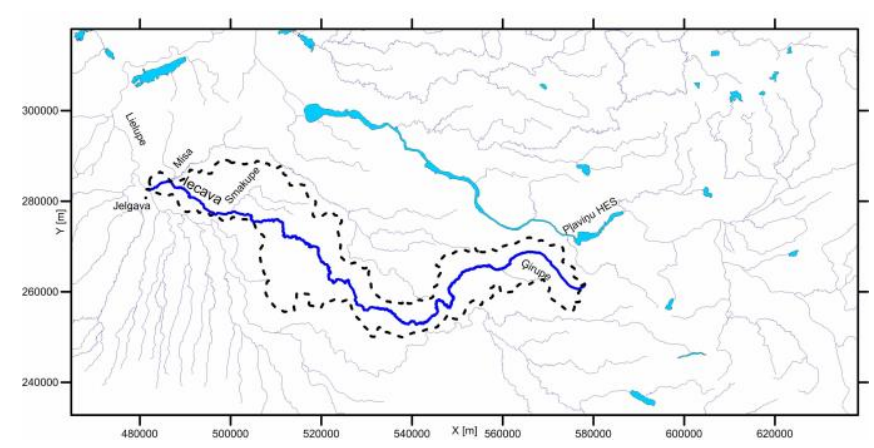

Fig. 3. Location of the Iecava river. The borderline of its drainage basin is shown.

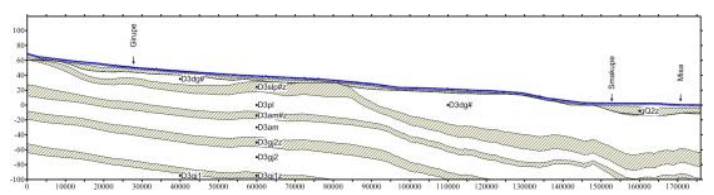

Fig. 4. Vertical cross-section along the Iecava river (above $100 \mathrm{~m}$ asl).

The attempt was made to locate the sources that support the base flow of the Iecava river. It was accomplished by using the particle tracking MODPATH program [4] that is joined with the MODFLOW program [5] which runs LAMO. In this paper, the unforeseen results of this numerical experiment are described.

\section{MATHEMATICAL FORMULATIONS}

To explain the role of particle tracking, some mathematics of steady state HM must be considered. By using the 3D finite -difference approximation, the $x y z$-grid of HM is built. It consists of $(h \times h \times m)$-sized blocks ( $h$ is the block plane step, $m$ is the variable thickness of a geological layer). For LAMO4, $h=250$ meters. The model constitutes a rectangular $u$-tiered $x y$-layer system where $u$ is the number of geological layers. For LAMO4, $u=27$ (Fig. 2).

LAMO provides the 3D-distribution of piezometric head vector $\varphi$ as the numerical solution of the boundary field problem which is approximated in the nodes of the HM xyzgrid by the following algebraic expression [3]:

$$
A \varphi=\beta-G \psi, \quad A=A_{x y}+A_{z},
$$

where $A$ is the matrix of the geological environment which is presented by the $x y$-layer system containing horizontal $\left(A_{x y}-\right.$ transmissivity $\left.T\right)$ and vertical $\left(A_{z}-\right.$ vertical hydraulic conductivity) elements of the HM grid; $\psi$ and $\beta$ are the boundary head and flow vectors, respectively; $G$ is the diagonal matrix (part of $A$ ) assembled by elements linking the nodes where $\varphi$ must be found with the locations where $\psi$ is given.

In $\mathrm{GV}$, the flows for rivers $q_{\text {rivers }}$ and lakes $q_{\text {lakes }}$ are simulated as follows [3]:

$$
q_{\text {rivers }}=G_{\text {rivers }}\left(\varphi-\psi_{\text {rivers }}\right), \quad q_{\text {lakes }}=G_{\text {lakes }}\left(\varphi-\psi_{\text {lakes }}\right)
$$

where $G_{\text {rivers }}$ and $G_{\text {lakes }}$ are diagonal matrixes (part of $G$ ) that assemble the elements linking the boundary conditions $\psi_{\text {rivers }}$ 
and $\psi_{\text {lakes }}$ (part of $\psi$ ) for the rivers and lakes with nodes of HM. These links control the interaction of the HM body with the rivers and lakes. In LAMO4, the elements of $G_{\text {rivers }}$ have been adjusted by accounting for data provided by the real measurements of the river streams [2].

For the particle tracking, the six groundwater flows (computed by MODFLOW) that pass through the faces of each finite-difference cell $(h \times h \times m)$ of HM were applied. MODPATH uses these flows to compute the paths for imaginary "particles" of the water moving through the simulated groundwater system [4]. In addition to computing particle paths, MODPATH computes the time of travel for the particles.

For a river, the starting locations of particles coincide with the cells where the river is attached to the HM body. These locations are fixed by the data carried by expression (2) for rivers. The Iecava river is linked with HM in 1027 nodes. In 985 and 42 nodes, accordingly, links belong to Q2 and D3dg\# aquifers. To find a path which reaches an unknown source of the river, the "reverse" tracking regime of MODPATH has to be applied when a particle moves in the upgradient direction. The particle stops and finds the source when it reaches a surface where the $\psi$-type boundary conditions of (1) is fixed. It mostly happens on the top surface of HM where the $\psi_{\text {rel }}$ (1st layer) is set. Some particles move towards the bottom $\psi_{\text {D2pr }}$ surface of HM (27th layer). Then the source is located beneath the thick regional aquitard D2nr\#. If a river is located close to the border of HM, the source may be located on the side border surface.

\section{FINDING BASE-FLOW SOURCES FOR THE IECAVA RIVER}

The Iecava river is an ordinary flat-land river that has a small specific slope. The 1027 cells joined with the Iecava river were used as the particle starting locations. None of the two small tributaries (Smakupe and Gerupe) were involved in order to make the numerical experiment simpler. The porosity value 0.1 was used for all layers of HM. The travel time of particles was not limited.

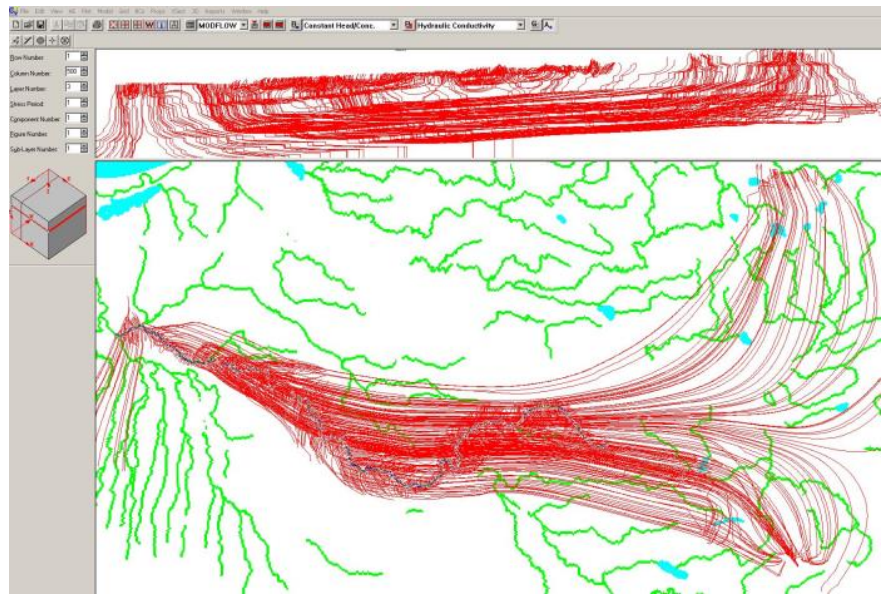

Fig. 5. Projections of pathlines on the $x y$ and $x z$ planes (GV graphics)
No unforeseen results of the particle tracking were expected. However, the result provided by GV (Fig. 5) was a surprise, because many base-flow sources were located very far from the river drainage basin and the paths of these particles had reached the deep layers of HM and then climbed up to enter the river.

In Fig. 6, the relationship between the number of particles and the length of their pathlines is shown. It can be deduced from the data of Fig. 6 that for 830 particles, the length of their pathlines does not exceed 20 kilometers; therefore, $81 \%$ of the particles have rather short pathlines.

In Fig. 7, the maximal travel time spent by the particles in the layers of HM is shown. Probably, the travel times that exceed 4000 years are spent by the particles with long pathlines. The time 30 thousand years is spent by the particles in the D2nr\# aquitard (layer No. 26).

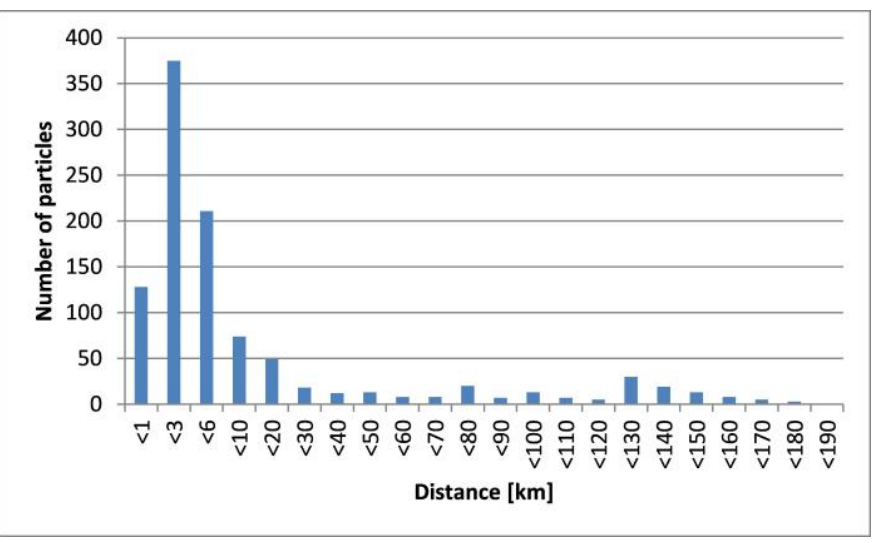

Fig. 6. The length of pathlines versus their number.

In Fig. 8, the number of particles that have attended aquifers of LAMO is given. The maximal number 1027 belongs to the third aquifer Q2. In the aquifers 1 and 27, the sources of the base-flow $\left(\psi_{\text {rel }}, \psi_{\mathrm{D} 2 \mathrm{pr}}\right)$ are located, and the sum of their numbers is 1027. Almost all particles must pass through the D3dg\# aquifer (layer No. 13), because it is placed beneath the Q2 aquifer.

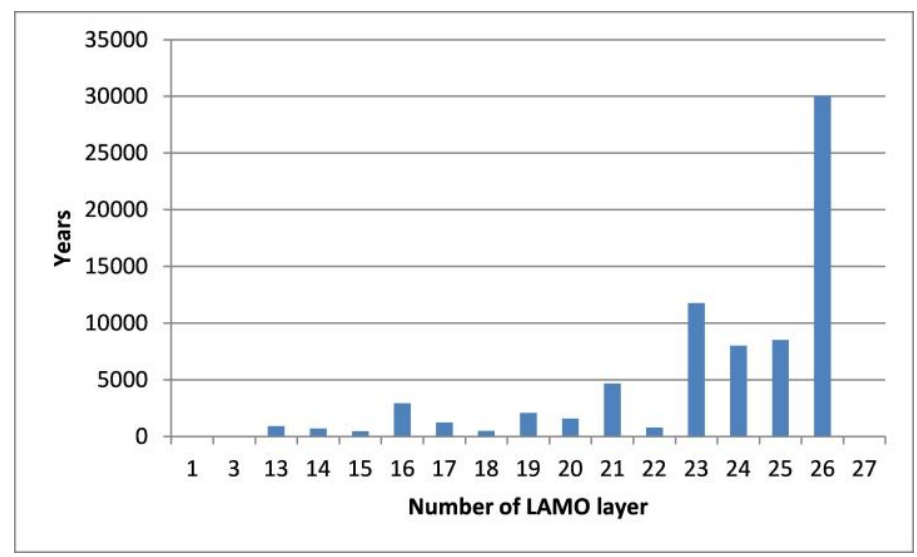

Fig. 7. Maximal travel time within layers. 


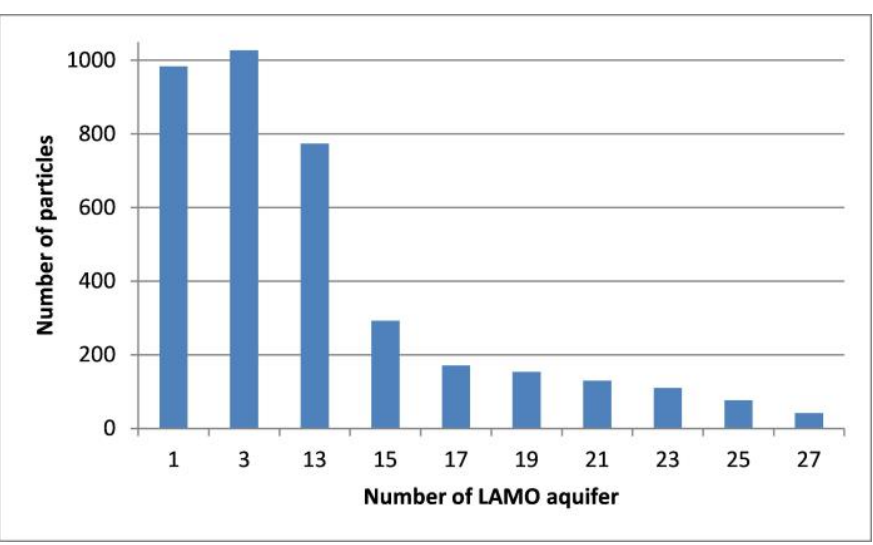

Fig. 8. The number of particles that have attended the aquifers.

In Fig. 9, the $x y$-projections for the particles Nos 800 and 1027 are shown. Both particles have long travel times (No. 800 - 8015 years; No. 1027 - 15353 years). The particles Nos 800 and 1027, accordingly, represent the sources located in the 1 st and 27th layer. Both sources are placed outside the river drainage basin.
In Figs 10 and 11, the vertical cross sections of the pathlines are shown for the particles Nos 800 and 1027 along their $x y$ projection lines (see Fig. 9). The vertical cross section of Figs 10 and 11 have been created by using SURFER [6] and the special software tools developed by the RTU specialists.

It can be concluded from the pathline in Fig. 10, that the appearance of the long pathlines which sources are far from the drainage basin are caused by the deep infiltration at the hilly areas of the country. There, a particle can reach a deeply located aquifer and then migrate a long distance, until the Iecava river is reached. In Fig. 10, the particle No. 800 passes through the D2brtz aquitard four times. This fact is caused by the vertical infiltration flows at these two locations where the particle enters the D2brt aquifer and then returns in the D3gj1 aquifer.

In Fig. 11, the vertical profile of the pathline No. 1027 is exposed. The particle comes from the D2prn aquifer (layer No. 27). It takes a long time to pass the thick aquitard D2nr\#. The particle climbs up under the influence of the ascending vertical flow, until the particle enters the Iecava river.

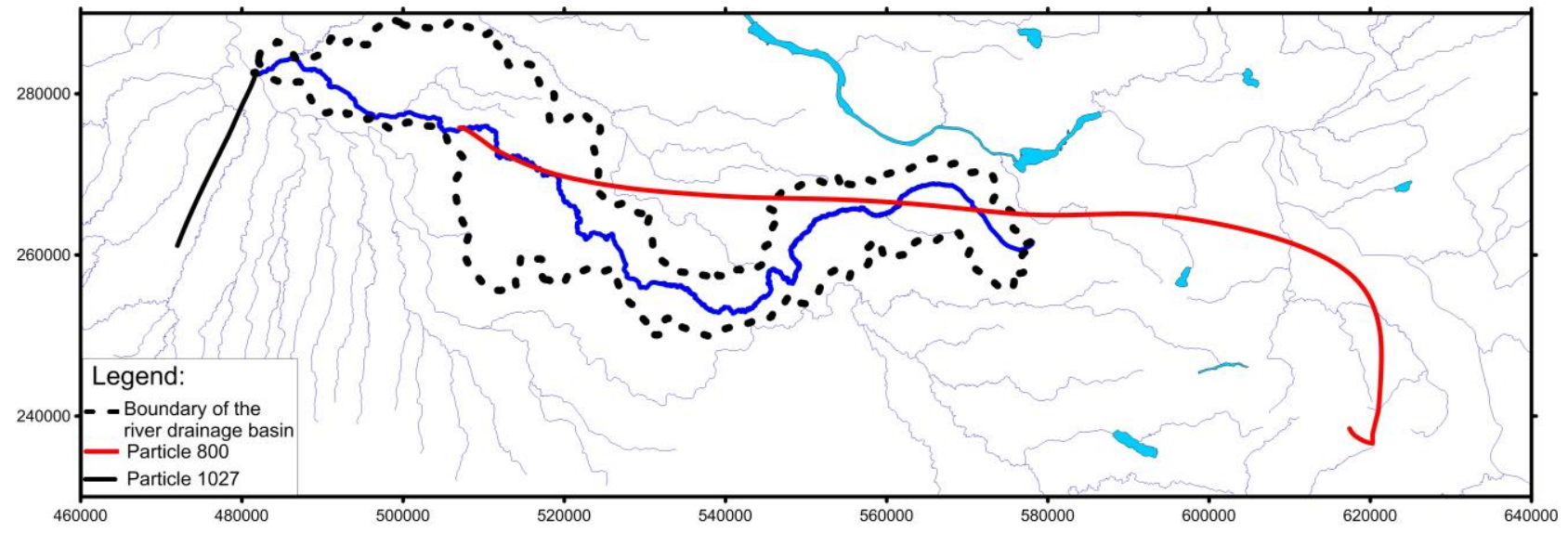

Fig. 9. Projections of the pathlines Nos 800 and 1027.

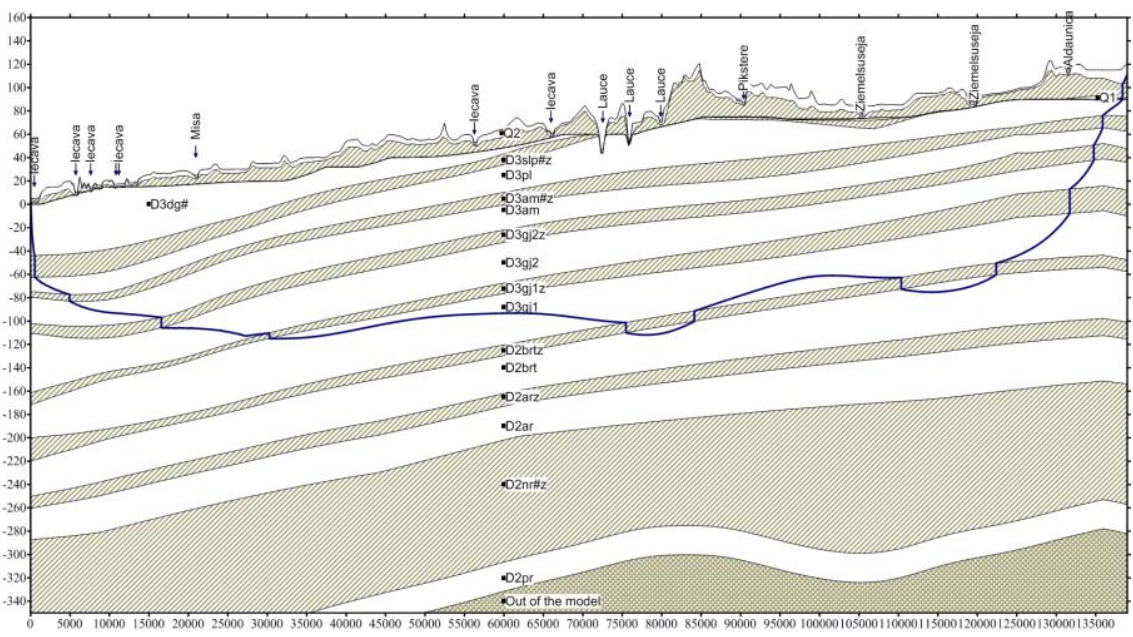

Fig. 10. Vertical cross-section along the pathline No. 800. 


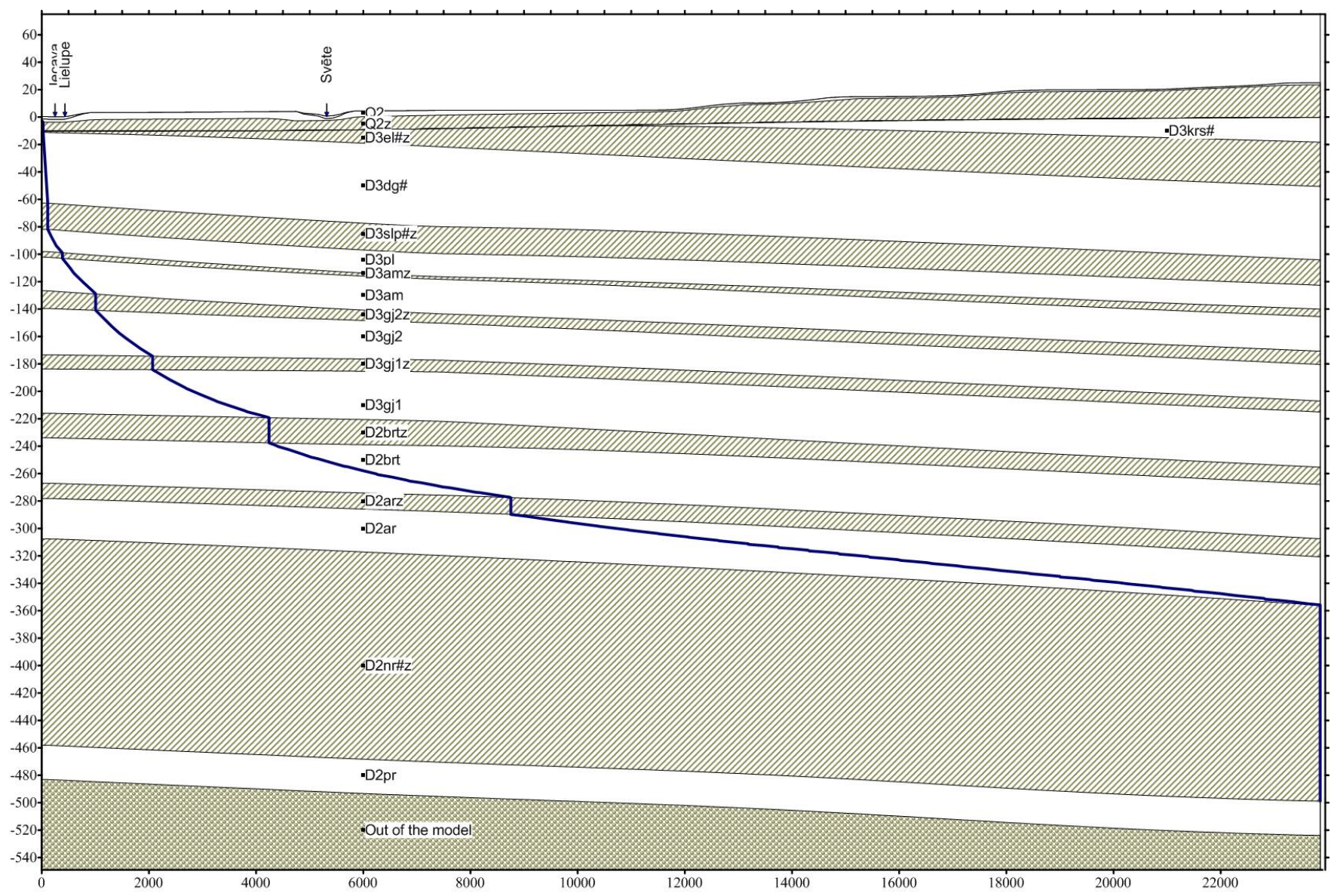

Fig. 11. Vertical cross-section along the pathline No. 1027.

\section{SORTING OF PATHLINES FOR THE IECAVA RIVER}

The above analysis of the simulation results for the Iecava river was done without sorting of pathlines that were obtained by using the MODPATH program (see Fig. 5). To get better understanding of the 1027 pathlines, they were sorted by using EXCEL [7] in seven groups by taking into account their tracking time (see Table II).

TABLE II

GROUPS OF SORTED PATHLINES

\begin{tabular}{|c|c|c|}
\hline No. of the group & Time, years & Number of pathline \\
\hline 1 & $0>25$ & 259 \\
\hline 2 & $0>25-100$ & 295 \\
\hline 3 & $0>100-400$ & 198 \\
\hline 4 & $0>400-1600$ & 68 \\
\hline 5 & $0>1600-6400$ & 84 \\
\hline 6 & $0>6400-128000$ & 86 \\
\hline 7 & $0>128000-35530$ & 37 \\
\hline & & In total, 1027 \\
\hline
\end{tabular}

The result of sorting is graphically shown in Figs 12-15. The $x y$ and $x z$ projections of the sorted pathlines are given for the groups $1-2,3-4,5-6$, and 7 . The superposition of the pathlines for the seven groups gives the common picture of Fig. 5. It can be concluded from Figs 12 and 13 that almost all pathlines of these four groups (maximal time -1600 years) are located within the river drainage basin. The $x z$-projections of the pathlines confirm the existence of descending and ascending groundwater flows within the basin. This fact can be partly explained by the groundwater flow balance data for the basin (Table 1). The sources for pathlines of the groups 5 , 6,7 are located outside the river drainage basin. The existence of these long pathlines can be discovered only if the large regional HM is used as the driver for the MODPATH system. The reported results were obtained when the particle was placed in the middle of the HM cell. The result depends on the vertical position (top, middle, bottom) of a particle within a cell. It should be investigated what happens if a group of particles is located within the HM cell. These results will be obtained when MODPATH, version 6 [8], will be included into the $\mathrm{GV}$ version 7. By using MODPATH, new knowledge about the nature processes of groundwater can be obtained. For example, in [9], very impressive results on geochemical processes were obtained when HM of the eastern part of Lithuania was used as the driver of MODPATH. 


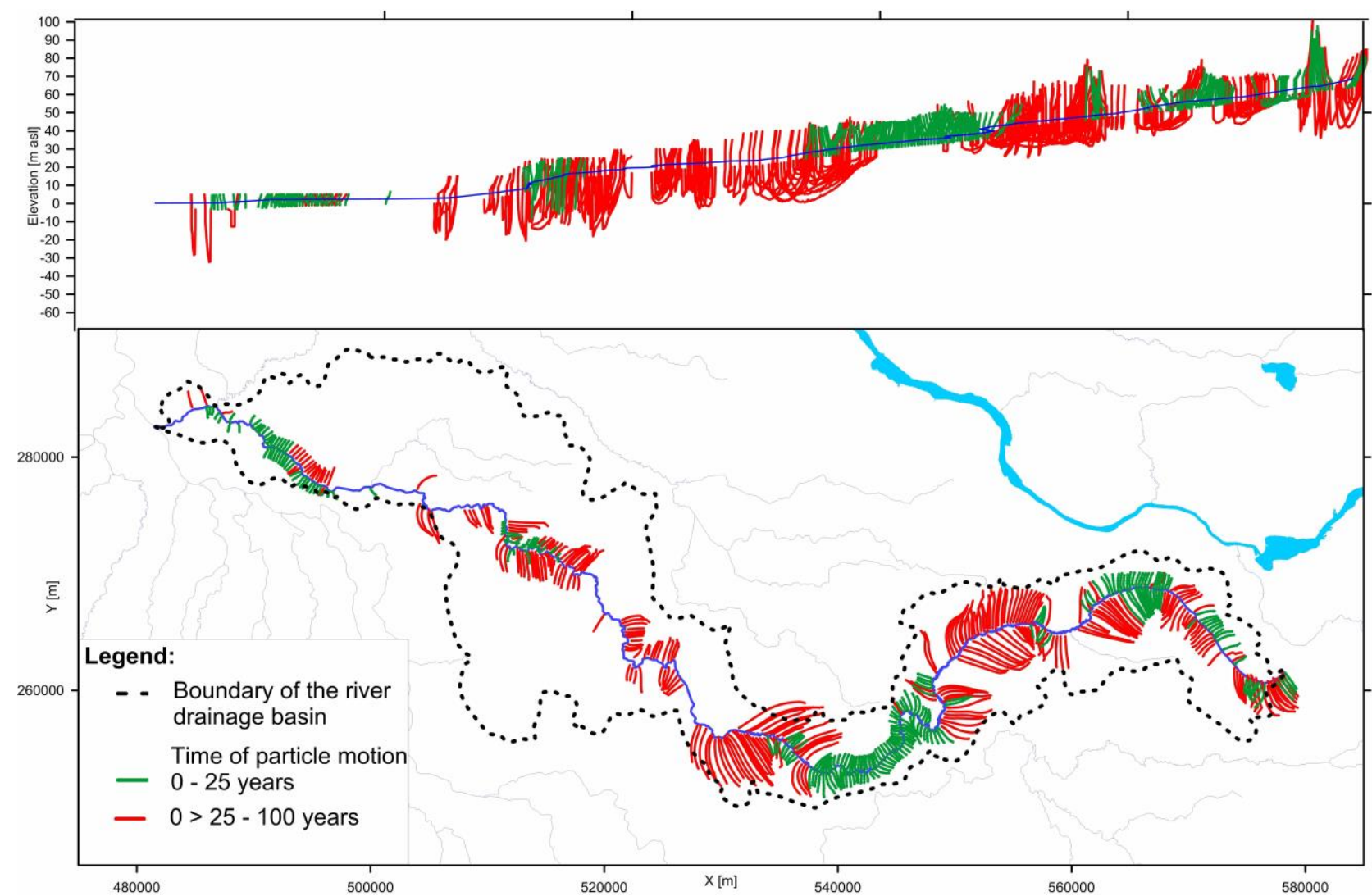

Fig. 12. Pathlines of the groups 1 and 2.

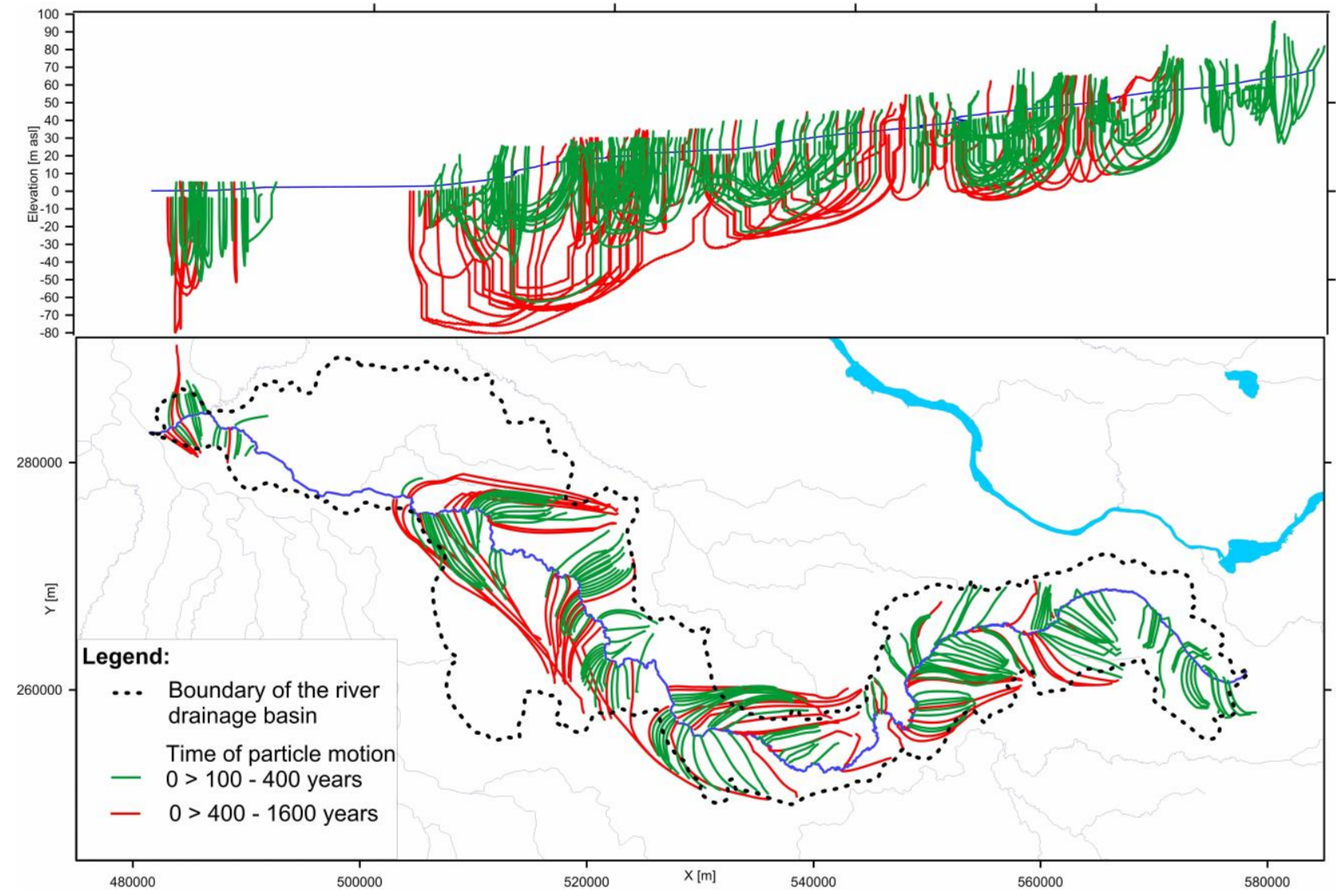

Fig. 13. Pathlines of the groups 3 and 4 . 


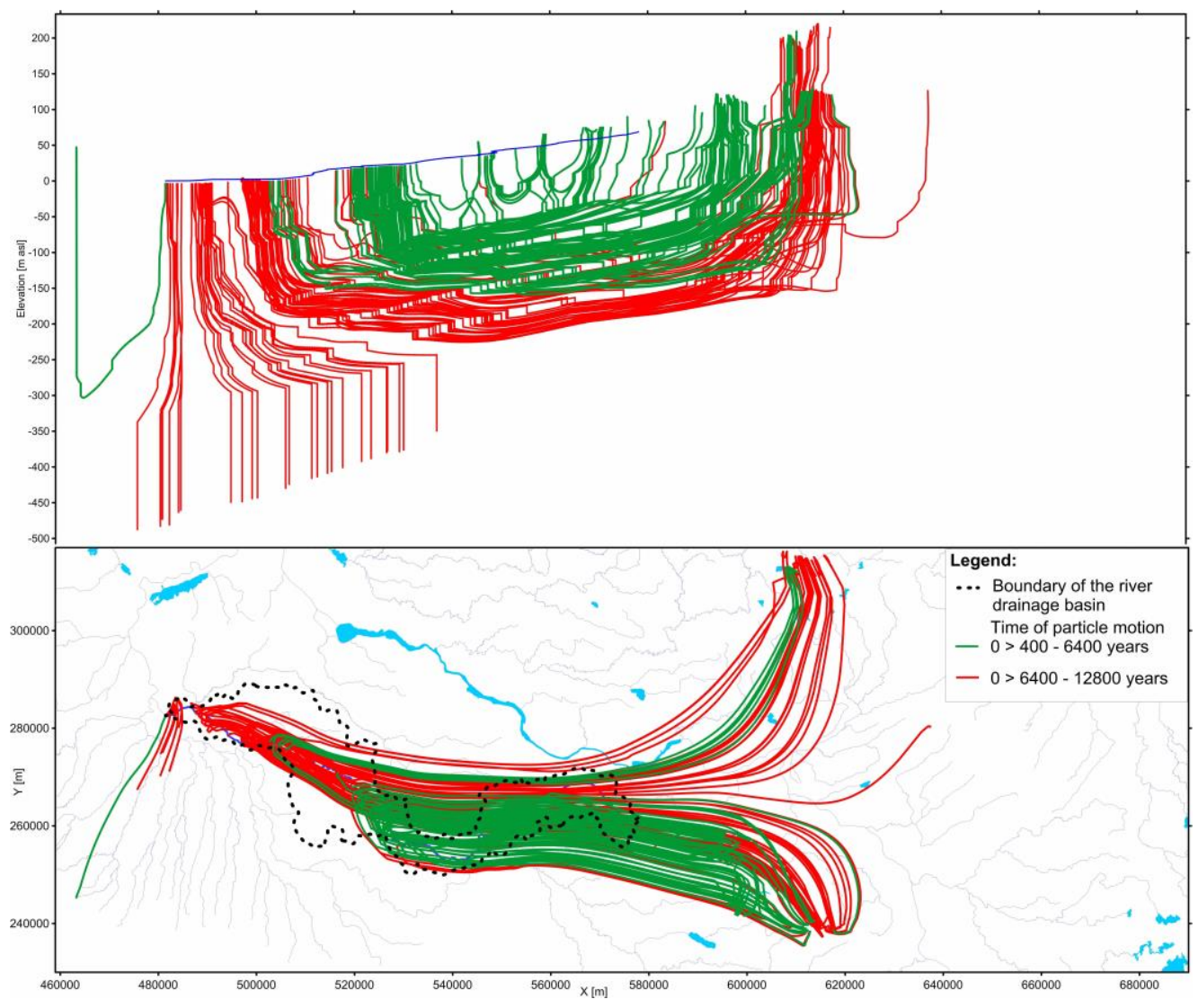

Fig. 14. Pathlines of the groups 5 and 6.

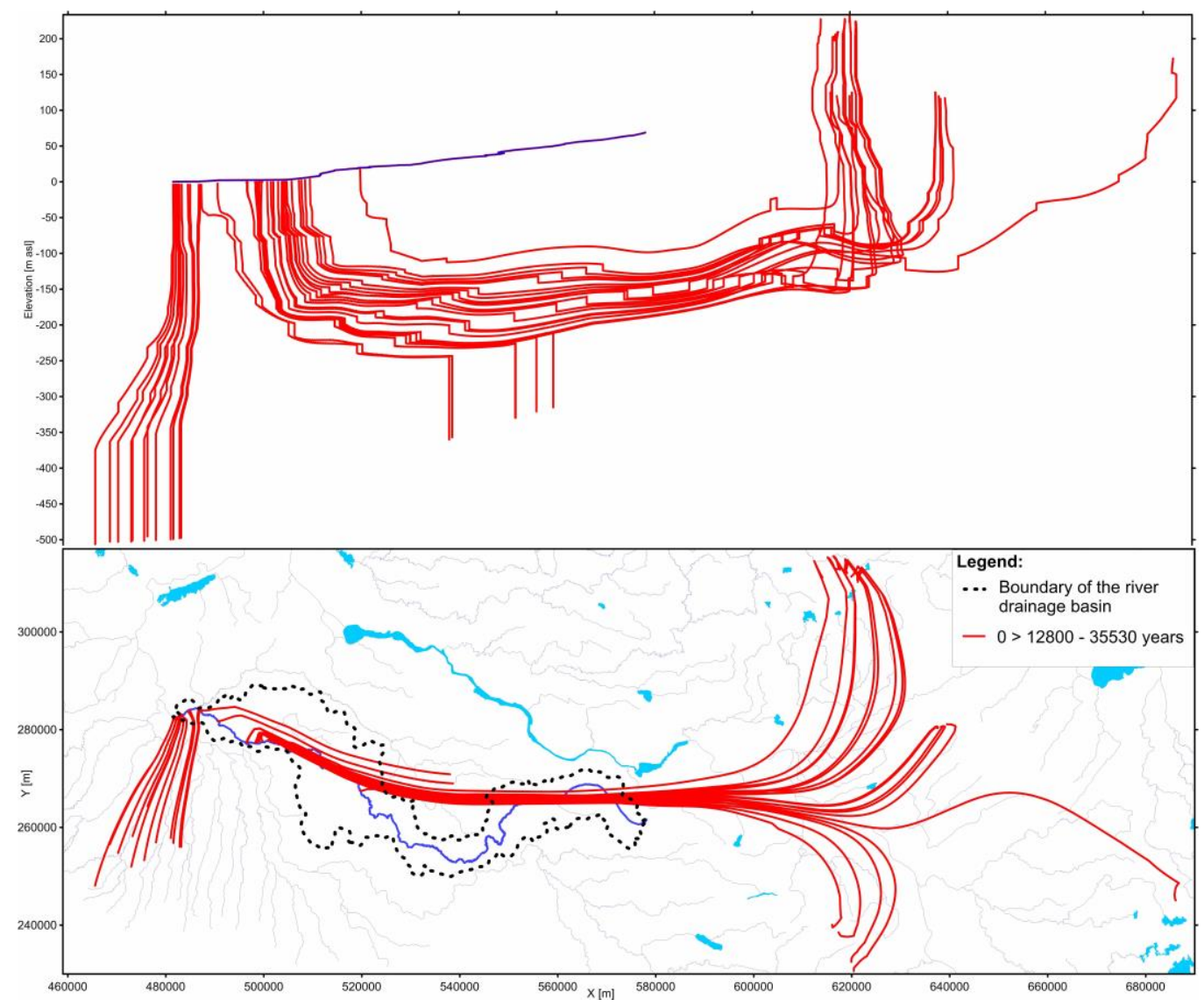

Fig. 15. Pathlines of the group 7. 


\section{CONCLUSION}

The hydrogeological model of Latvia, version LAMO4, was used as the driver for the MODPATH program. The attempt was made to find sources of the river base flow of the Iecava river. Unforeseen results were obtained: many sources were located very far from the river drainage basin; even within the basin, the shape of pathlines is very complex. The results of this numerical experiment demonstrate usefulness of applying a large regional HM, like LAMO4, for investigating the complex processes of nature.

\section{ACKNOWLEDGMENT}

In 2010-2012, the hydrogeological model of Latvia LAMO1 was developed within the framework of the Riga Technical University project that was co-financed by the European Regional Development Fund. The current upgrades of LAMO3 and LAMO4 are supported by the Latvian State Research program EVIDEnT.

\section{REFERENCES}

[1] Environmental Simulations, Inc. Groundwater Vistas. Version 6, Guide to using, 2011.

[2] A. Spalvins, J. Slangens, I. Lace, O, Aleksans, K. Krauklis, V. Skibelis, I. Eglite, "The Novel Updates of Hydrogeological model of Latvia," Scientific Journal of Riga Technical University Boundary Field Problems and Computer Simulation. vol. 54, Riga, RTU, 2015. http://dx.doi.org/10.7250/bfpcs.2015.005

[3] A. Spalvins, J. Slangens, I. Lace, O. Aleksans, K. Krauklis, "Improvement of hydrogeological models: a case study," International Review on Modelling and Simulations (I.RE.MO.S.), Praise Worthy Prize, Naples, Italy, vol. 8, no. 2 April 2015, pp. 266-276.

[4] D. W. Pollok, User's Guide for MODPATH/MODPATH-Plot, Version3. A particle tracking post-processing package for MODFLOW, the US Geological Survey finite-difference groundwater flow model, U.S. Geological survey, September 1994

[5] A.W. Harbaugh, MODFLOW-2005, U.S. Geological Survey Modular Ground-Water Model: the ground-water flow process, chap 16, book 6 , US Geological Survey Techniques and Methods 6-A16, USGS, Reston, VA.

[6] Golden Software, Inc., SURFER-13 for Windows, Users manual, Guide to Using, 2015.

[7] J. Walkenback, Excel-7 Bible, Wiley Publisching, Inc. Indeanopolis, Indian, 2007, p. 808.

[8] D. W. Pollock, "User Guide for MODPATH Version 6-A ParticleTracking Model for MODFLOW," 2012 [Online]. Available: http://pubs.usgs.gov/tm/6a41/pdf/TM_6A_41.pdf, [Accessed Nov. 17, 2015].

[9] R. Mokrik, V. Juodkazis, A. Stuopis, and J. Mazeika, "Isotope geochemistry and modelling of the multi-aquifer system in the eastern part of Lithuania," Hydrogeology journal., vol. 22, 2014, pp. 925-941. http://dx.doi.org/10.1007/s10040-014-1120-6

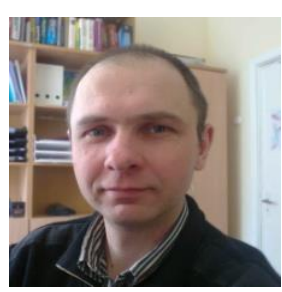

Kaspars Krauklis received the Master's degree in Computer Systems from the Riga Technical University in 2007 and the Certificate in Teaching of Engineering Sciences from the Institute of Humanities of RTU in 2005. He is a researcher at the Environment Modelling Centre of RTU.

E-mail: kaspars.krauklis@rtu.lv

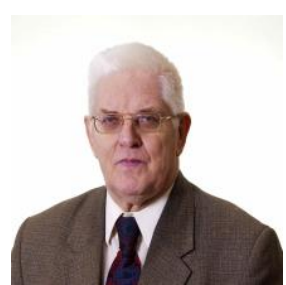

Aivars Spalvins was born in Latvia. In 1963, he graduated from the Riga Polytechnical Institute (since 1990 - Riga Technical University) as a Computer Engineer. A. Spalvins is the Head of the Environment Modelling Centre of RTU. His present scientific interests include computer modeling of groundwater flows and migration of contaminants.

E-mail: aivars.spalvins@rtu.lv

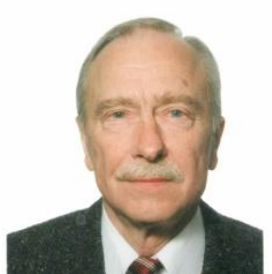

Janis Slangens was born in Latvia. In 1969, he graduated from the Riga Polytechnical Institute (since 1990 - Riga Technical University) as a Computer Engineer. J. Slangens is a senior researcher at the Environment Modelling Centre of RTU. His research interests include computer modeling of groundwater flows.

E-mail Janis.slangens@rtu.lv 